\title{
Hoover and the Hawley-Smoot Tariff: A View of Executive Leadership
}

J. Richard Snyder

THE HAWLEY-SMOOT TARIFF of 1930 has long been evaluated by economists and historians as a major economic miscalculation. Herbert Hoover's reputation as a legislative leader has suffered equally from the charge that he let Congress run amuck in constructing tariff rates and that he therefore shares the burden of responsibility for enactment of exhorbitant duties in 1930. The time has not yet arrived to whitewash the Hawley-Smoot act, nor to disparage the welltaken and documented criticisms of those who have seen it as a major mistake for the nation's consumers and exporters and for the international trading community. But what can be stated is that the generally accepted portrait of Hoover's executive leadership during consideration of the Tariff of 1930 has tended to be overly critical of the President. Previous examinations of the controversy have focused almost entirely upon the rates themselves and have thereby avoided the significant, difficult, and informative struggle between the President and the Senate over the Tariff Commission's role in future tariff adjustment. That struggle, it now appears, was as equally significant as the one over the rates themselves. For Hoover's fight with Congress over the question of who would control the Tariff Commission, and consequently, who would control rate changes, illuminated a reaction against the extreme protectionist policy of the $1920 \mathrm{~s}$, revealed a sympathy for lower rates in general, and suggested a strong Senate desire for aggressive American leadership in reducing 
world trade barriers. ${ }^{1}$

This challenge to Hoover came from several sources. Representatives of farming regions saw in the President's continued control of the Commission an opportunity for him to elevate further already high rates on industrial goods. A coalition of progressive Republicans and Democrats, reacting against executive domination of the agency in the 1920s, were bent on denying Hoover a similar opportunity. And the growing conviction among many members of the Senate that the traditional policy of high protection did not serve well the commercial needs of the United States, heightened concern over who was to control the board and give effect to its findings.

The Tariff Commission, created during Woodrow Wilson's administration, had been given responsibility in the Fordney-McCumber Act of 1922 to evaluate the tariff and to recommend changes up to fifty percent of existing rates which would equalize production costs for firms, domestic and foreign, competing in the American market. ${ }^{2}$ Controlled by Harding and Coolidge, the agency had failed to attack trade barriers on items important to farmers, consumers, and some manufacturers. Disturbed, the Senate created a special investigative committee, chaired by Senator Joseph T. Robinson of Arkansas, to evaluate the Commission and the usefulness of Section 315 of the Fordney Act; the clause which per-

${ }^{1}$ Broadus Mitchell, Depression Decade (New York: Holt, Rinehart, 1947), 72; Arthur M. Schlesinger Jr., The Crisis of the Old Order, 19191933, Vol. I of The Age of Roosevelt (Boston: Houghton Mifflin, 1964), 164; John D. Hicks, Republican Ascendency, 1921-1933 (New York: Harper and Row, 1960), 222; Frank W. Taussig, Tariff History of the United States (8th ed.; New York: G. P. Putnams, 1931), 522-526. Mitchell and Hicks miss the point when they criticize Hoover for failing to guide the tariff more closely during passage. That being a hopeless task, the President focused upon the flexible provision which he guided very well indeed. Harris Gaylord Warren, Herbert Hoover and the Great Depression (New York: Norton Press, 1967), 84-85. Warren interprets opposition to the Hoover proposals for a flexible clause to be composed of those who were concerned only with their immediate interest and indifferent to the national welfare.

${ }^{2}$ U.S., Congressional Record, 67th Cong., 2nd Sess., 1922, LXII, Part II, 11240. 
mitted executive adjustment of rates. After stretching its hearings out over nearly two years, the Robinson Committee reported in early 1928 that the flexible tariff had no practical value. Tariff-making should be an exclusive Congressional duty, and Robinson asked Congress to return the agency to its pre-1922 function of simply gathering data. During his presidential campaign in 1928, Hoover agreed. But once elected, he promptly reversed himself, ${ }^{3}$ arguing that what the Commission needed was Hoover appointees who could administer it more effectively.

The President's tariff attitude was well within traditional Republican policy, and when one reflects upon Al Smith's promise during the campaign to protect American business 'to' the very limit,' Hoover's views might be characterized as well within the mainstream of political thought in the late 1920s. He believed in government protection of industry, agriculture, and labor from the competition of low priced foreign goods. He readily accepted the idea that production costs of producers competing in the American market should be equalized. But he did not hold that the national economy could become self-contained and self-supporting. Indeed, much of his work as Secretary of Commerce had focused on the necessity of assuring an inexpensive and certain foreign supply of raw materials for American manufacturers, and of opening up markets abroad for surpluses produced in the United States. His program for farmers, partly embodied in the Agricultural Marketing Act of 1929, envisioned a more centralized structure through which to stabilize farm prices at home while aggressively seeking markets abroad. But Hoover also hoped

${ }^{3}$ I. Richard Snyder, "Coolidge, Costigan, and the Tariff Commission," Mid-America L (April 1968), 131-148; U.S., Congress, Senate, Select Committee Investigation of the United States Tariff Commission, 69th Cong., lst Sess. (Washington, D.C.: Government Printing Office, 1928); U.S., Congressional Record, 70th Cong., Ist Sess., LXVIX, Part 10, 10547; Nevin Neal's assessment of the Robinson Committee's recommendations is erroneous, "A Biography of Joseph T. Robinson," unpublished Ph.D. dissertation, University of Oklahoma, 1958), 205; Neal states that the Committee recommended that the Tariff Commission be allowed to establish new rates independently of the President, Washington Post, Octobr 16, 1928. 
to help the farmer through outright tariff protection. $\mathrm{He}$ stepped upon the escalator of rate revision to aid economically depressed rural regions, to allay commercial fears in industry, to satisfy wage conscious laborers, and to reassure the presumably price conscious consuming public. Just as progressives had done before him, he became convinced that the major economic evils in tariff legislation could be handled through the flexible clause and the Tariff Commission, and as did reformers before him, he found the experiment a great trial. ${ }^{4}$

Calling Congress into special session, he charged that the major weaknesses of rate revision through the flexible tariff clause had been the politically biased operations of the previous board, the pettiness of its commissioners, and its lethargy in delivering quick decisive conclusions which could guide the President in changing duties. The flexible provision must remain, Hoover argued, but the Commission would have to be reorganized to make the elastic clause more effective. From the beginning of his administration, then, Hoover linked his proposals for rate change with continuation of the flexible tariff idea and a reorganized Tariff Commission. With adequate rate elasticity, the nation could look forward to economic stability and security. Without this safeguard, business, agriculture, and the consumer would continue to face periodic log-rolling revisions, an unacceptable intrusion into the economy."

In moving to deal with the tariff and by implication commercial policy, Hoover acted against a background of Republican protectionism and the United States rejection of international efforts to reduce trade barriers. Republicans during the 1920s continued to regard the tariff as a purely domestic issue, although Wilson had clearly pointed out that such a

\footnotetext{
${ }^{4}$ Washington Post, October 14, 15, 1928; Warren, Herbert Hoover (New York: Oxford University Press, 1959), 47-84-86, 92. The flexible clause, a provision of the 1922 Fordney-McCumber Tariff, allowed the President to change tariff rates by as much as 50 percent, after investigation of proposed adjustments by the Tariff Commission.

${ }^{5}$ U.S., Congressional Record, 71st Cong., Special Sess., 1929, LXXI, Part 1, 6, and 71st Cong., 1st Sess., 1929, LXXI, Part 1, 42-43.
} 
stance could not answer the need for international leadership by the world's major creditor and exporter. While the decade was marked by satisfactory levels of exports from the United States, this merchandise was subsidized by American loans abroad. As John Foster Dulles put it in 1926, "control over foreign loans implies control of the foreign commerce of the United States." The danger, of course, was any sequence of events which would shake the flow of dollars going abroad or restrict American markets to foreign producers, thereby reducing foreign purchasing power and creating strong pressures for nationalistic, economic retaliation against the United States. A series of international conferences creating a bargaining framework for tariff reduction would generate a far more sound basis for world commerce and reward the American search for markets. But the United States had specifically instructed its delegates to the Geneva Conference on Trade in 1927 to sidetrack if possible any resolution calling for reduced tariffs. And despite the possibility of negotiating rate reductions through Section 315, Harding and Coolidge had refused to spread tariff concessions through use of the unconditional form of the most-favored-nation clause, adopted by the State Department in $1923 .{ }^{6}$

Hoover did not intend to depart from this tradition. But

${ }^{6}$ William Diamond, The Economic Thought of Woodrow Wilson (Baltimore: Johns Hopkins Press, 1943), 132-134; Ray Stannard Baker and William E. Dodd, eds., Woodrow Wilson: The New Democracy, Presidential Messages, Addresses, and Other Papers, 1913-1917 (6 vols.; New York: Harper and Brothers, 1925-1927), V, 492-493, 568-569, VI, 430-431, 533-534; Don B. Humphrey, American Imports (New York: Twentieth Century Fund, 1955), 103; Norman Davis, undated memo. in file with Benjamin B. Wallace Memorandum of April 1927; Summary Reports of Preparatory Subcommittee on Customs Tariffs for International Economic Conference, April 14, 1927, Norman Davis Papers, Manuscript Division, Library of Congress: Richard C. Snyder, "The Most-Favored-Nation Clause and Recent Trade Practices." Political Science Quarterly, LV (March 1940), 81-82; André Siegfried, "European Reactions to American Tariff Proposals," Foreign Affairs, VIII (October 1929), 13-15; John Foster Dulles, "Our Foreign Loan Policy," Foreign Affairs, V (October 1926), 33-48; J. Richard Snyder, "William S. Culbertson and the Making of Modern American Commercial Policy, 1917-1925," Kansas Historical Quarterly, XXXV (Winter 1969), 396410. 
he wanted tariff revision, and he wanted executive control over future rate adjustments; a control that threatened those who saw American commercial policy as anachronistic in the trading world of the 1920s. Despite the Robinson Committee's criticism of executive handling of the Tariff Commission, despite hostile rural Republicans disillusioned by party rejection of the various farm debenture proposals, and confronted by Democrats unhappy with the use of tariffs, Hoover designated participation of the Commission in future rate adjustment and the executive control of that agency as the sine qua none of a new tariff bill. Well acquainted with the log-rolling that had characterized tariff legislation in the past, he intended to rely upon the flexible clause to adjust duties outrageously overprotective and detrimental to the national interest as he saw it. Similarly, he wanted power to adjust rates which proved inadequate in protecting business as conditions changed and competition from abroad increased. Such a policy would continue Republican protection erected in the 1920s and extend the tenuous thread by which the United States was forced to "spend itself rich" through loans to foreign purchasers. Hoover's first major action as President, then, was to propose, without serious reconsideration and in the face of much restlessness in Congress, a policy both economically short sighted and politically risky.

Representative Willis C. Hawley, Chairman of the House Ways and Means Committee, echoed Hoover's call for tariff adjustment and revision of the administrative clauses, particularly those dealing with the flexible tariff. But in a minority report Cordell Hull accused Republicans of trying to give the President power to adjust the tariff upward. Under the principle of rate revision advanced by Hawley, the Chief Executive could equalize "conditions of competition" rather than "costs of production" as the Fordney Act has stipulated. The phrase "conditions of competition" was far more vague than the latter, and open to an interpretation which would justify ever higher increases in duties. Hull charged that the flexible tariff had been used previously to raise tariffs, not to lower them, and that the incompetence of commissioners appointed by Coolidge and Harding was already acknowledged to be a 
national scandal. Presidential control of the tariff would make a bad law worse, for Republicans were building safeguards for the home market in the face of a capacity for overproduction of goods and services totaling twenty to twenty-five billion dollars a year. This surplus was so great as "to constitute an additional and dominant factor in determining our tariff and commercial policy." Congress should oppose Republican tariff traditions and executive control of the tariff and inaugurate, instead, a policy of moderate, reasonably competitive rates which would "increase healthy production, maintain wages, and find world markets for our ever-increasing surpluses." Hull's remarks reflected an attitude long recognized by important exporting sectors of the business community and the State Department, though Congressional politics had not yet fully recognized it. But some politicians may have been more sensitive to pleas similar to those of Edward A. Filene of Boston who argued that only through entry into ever larger markets could manufacturers successfully employ the mass production techniques which permitted large volume-small profit per unit. Without these methods manufacturers could neither keep prices low enough to allow consumers to purchase goods produced, nor support labor's standard of living. ${ }^{7}$

To the President, the most critical part of the new tariff act was its authorization for executive rate adjustment. And it was clear that Hoover had the protests of Hull and his sup-

${ }^{7}$ U.S. Congress, House, Ways and Means Committee, Report on H.R. 2667, Tariff Act of 1930, 71st Cong., 2d Sess., Report No. 7, 3-9, 163167; U.S., Congress, House, Minority Report of Members, Ways and Means, Committee, on H.R. 2667, Tariff Act of 1930, 71st Cong., 2d Sess., 1-3; For a general description of the increased attention foreign markets had been gaining among businessmen and those who dealt with business needs see Walter LaFeber, The New Empire: An interpretation of American Expansion, 1860-1898 (Ithaca: Cornell Univ. Press, 1963), 413; David Healy, U.S. Expansionism: The Imperialist Urge in the 1890's (Madison: University of Wisconsin Press, 1970), 161; Carl P. Parrini, Heir to Empire: U.S. Economic Diplomacy, 1916-1923 (Pittsburgh: University of Pittsburgh Press, 1969), passim; William Appleman Williams, Tragedy of American Diplomacy (Rev. Ed.; New York: Dell Publishing Co., 1962), 106-159; Edward A. Filene, "Mass Production and the Tariff," Annals of the American Academy of Political and Social Science ( January 1929), 45. 
porters well in hand. During legislative conferences with party leaders on May 9 and May 22, 1929, he indicated that he would veto any tariff bill which did not contain the flexible clause, and at the end of the month, the House sent the Senate what he wanted. Then, Senator Reed Smoot's Finance Committee encouraged adoption of the new phrase "conditions of competition" as a guideline for executive rate adjustment. Smoot further urged his colleagues to direct the Tariff Commission to draw up a structure of converted rates based upon the "domestic value" of imports rather than the "foreign value" which the customs houses had historically used. Such a changed standard, if accepted by Congress, would have the immediate effect of raising the tariff significantly unless duties were correspondingly reduced at the same time. ${ }^{8}$

It was at this point that Hoover's critics had an opportunity to deal with his policy. The demands of log-rolling, in effect, prohibited attempts to curtail tariff increases on the floor of the Senate. Each member had special projects to protect and to gain support for them he was forced to vote for the peculiar needs of others. But on the question of the flexible clause and future control of the Tariff Commission, the specific needs of districts and states could give way to a more general concern about tariff levels, consumer interests, and commercial policy. And for Senators from rural regions who had endured Coolidge's opposition and knew of Hoover's hostility to any export debenture scheme, the only opportunity to limit further increases in industrial tariffs would come from their sizable minority in the Senate. Senator Borah came out against Smoot's projections for the Commission, and Senators William King of Utah and Furnifold Simmons of North Carolina introduced amendments to strike Section 336, the flexible provision, from the bill. Hoover pleaded that this clause would remedy a tariff which was bound to be imperfect. Flexible rate revision would keep the nation abreast of chang-

\footnotetext{
${ }^{8}$ Herbert Hoover, Memoirs: The Cabinet and the Presidency, (New York: Macmillan Co., 1952), II, 293; U.S., Congressional Record, 71st Cong., 1st Sess., 1929, LXXI, Part 2, 1995-1998; U.S. Congress, Senate, Report From Committee on Finance to H.R. 2667, Tariff Act of 1930, 7lst Cong., 1st Sess., Report No. 37, 64-79.
} 
ing world trade and constituted "one of the most progressive steps taken in tariff making in all our history." But the dissidents-Norris (R), Howell (R), La Follette (R), Nye (R), Borah (R), Blair (R), Walsh of Montana (D), George (D), and Simmons (D), joined by Walsh of Mass. (D), Tydings (D), and others-were unimpressed. They attacked the constitutionality of the flexible provision, raised the probability that further increases in duties would restrict foreign markets important to the United States, and argued that executive control of the Commission would harm consumers and farmers. Senator Robinson carried the debate to the public in a national radio address over NBC which asserted that ever higher protection would merely protect goods barely produced in the United States and make it impossible for foreign customers to earn the dollars they needed to buy American exports. ${ }^{9}$

This coalition of progressive Republicans and Democrats viewed the flexible provision as the most important issue in the tariff fight of 1929-1930, as did Hoover. Only with an elastic clause which left the power to change rates in the Congress could they be assured that future tariff adjustments would treat domestic producers and consumers fairly, and encourage expansion of world markets. The lines formed very firmly on Section 336, Senator Robinson noted, and he labeled the fight as "the most important issue in this bill." To those who doubted that Congress could consider recommendations from the Commission without indulging in a renewed orgy of log-rolling, Senator Norris offered a solution. Keep the flexible clause, he suggested, but prohibit amendments to Commission reports forcing Congress to either accept or reject the agency's recommendations. This compromise would provide Congressional review of rate revision, eliminate presidential authority over duties, and curtail log-rolling. Furthermore, it would have the virtue of salvaging the flexible

"U.S. Congressional Record, 71st Cong., 1st Sess., 1929, LXXXI, Part 3, 3410, Part 4, 3867, 3927, 4134; Gilbert C. Fite, George N. Peek and the Fight for Farm Parity (Norman: University of Oklahoma Press, 1954), 224; Neal, "Robinson," 335; Darwin N. Kelly, "The McNary Haugen Bills, 1924-1928," Agricultural History, XIV (Oct. 1940), 170180 . 
clause. For the business community-the National Association of Manufacturers, the United States Chamber of Commerce, the National Grange, and the American Farm Bureau -strongly supported some device which would allow constant modifications of the tariff. In late September, 1929, Hoover had indicated that he would settle for a law binding him to accept or to refuse Commission recommendations, though he would not surrender his control over final action. But dissidents were equally adamant about relocating control of proposed changes back with the Congress. In the words of Senator Fred Sackett of Kentucky, "as goes the flexible provisions so goes the bill." Hoover threatened to veto any measure containing the Norris Amendment, but dissidents ran it through the Senate, 47-42. A coalition of 34 Democrats and 13 Republicans defeated 37 Republicans and 5 Democrats who voted against Norris' proposal. ${ }^{10}$

Encouraged by their majority on the flexible clause issue, dissidents approved Smoot's recommended study of the American valuation system, pointing out that Congress would have to learn what reductions in rates would be necessary if the new method were adopted. They also forced the Senate to adopt an amendment requiring the Tariff Commission to make available to Congress information compiled on the costs of production. Smoot argued that this rule would deny the board access to data, for manufacturers would not reveal costs which could become public knowledge. Borah retorted that if Congress were going to do someone a favor, it should have all available information. The amendment passed, 47-29. Finally, responding to the plea that consumers had no effective voice when tariff schedules were discussed, dissidents adopted Hugo Black's amendment creating a Consumers Counsel to represent the "average purchaser" during the Commission's hearings. The counselor was never to have represented either himself or a client before Congress or the Commission and was to appear before the agency in all its proceedings. He could offer and respond to testimony, examine

${ }^{10}$ U.S. Congressional Record, 71st Cong., 1st Sess., 1929, LXXI, Part 4, 4013, 4040, 4080, 4084, 4117, 4149-4150; Hoover, Memoirs, II, 294. 
and cross examine witnesses, subpoena data and draw information from Commission files. The measure passed, 68-11. In March, 1930, the Senate approved the tariff bill, as amended, 53-31. This challenge to Hoover by progressive and Democratic Senators constituted a major exception to David Burner's thesis that the Democratic-progressive alliance broke down after 1924. The fight over the Tariff Commission, because it was the major issue of the Hawley-Smoot Act, also repudiates Burner's argument that Democrats cared less about the tariff as a political issue after 1924. They cared-but politically they could deal with it only through the issue of the flexible tariff and the Commission. The same point can be made for Frank Fetter's argument that there was no debate over free trade and protection in 1929-1930. The discussion, as Fetter pointed out, was over the best way to apply the protective principle. In that context, the role of the Commission and the President in adjusting the tariff was central to the conflict. ${ }^{11}$

In preparing to deal with the conference committee and to defend his program, Hoover was able to draw upon vast resources-the Commission, business manufacturers, and his powers as Chief Executive. The Commission maintained close communications with the President, sending him names of Congressmen and Senators of both parties who had applied for increases in duties through the agency, and providing him with information on world trade, newspaper editorial opinion, and a wide range of other data. From the business community, both the National Association of Manufacturers and various Chambers of Commerce, Hoover elicited indirect pressure and outright lobbying in Congress, on behalf of the flexible provision. The National Association of Manufacturers reassured the President that he could count "absolutely" on its support for the flexible tariff and for his "positive determination to have established for the manufacturers of the

\footnotetext{
${ }^{11}$ Ibid., 4158, 4175, 4564-4570, 4613, 4626-4627; 71st Cong., 2d Sess., 1930, LXXI, Part; David Burner, Politics of Provincialism: The Democratic Party in Transition, 1819-1932 (New York: Knopf, 1968) 161, 168p Frank W. Fetter, "Congressional Tariff Theory," American Economic Review, XXIII (September 1933), 416-419, 427.
} 
nation a Tariff Commission which will function as an economic agency for public welfare." ${ }^{2}$

Labor's role in the flexible tariff controversy was weak and erratic. Contrary to the pleadings of Matthew Wohl, who urged the American Federation of Labor to take a stand on the issue of rates and control of the Commission, organized labor remained cautious. William Green was willing to plead for increased duties on some industrial products, but refused to take an early position on the administrative features of the tariff. Later he supported Hoover's flexible provision proposal. ${ }^{13}$

Still, with all this support, Hoover faced a difficult fight. Many dissidents freely agreed with Representative Frederick Davenport of New York who warned that without agreement on the Commission's function there might be no tariff bill at all. Thomas Marvin, Chairman of the agency, wrote Hoover that the battle would be especially difficult because dissidents were voting their convictions rather than political judgments. Their arguments had clearly carried the day in the Senate, convincing Robert Wagner of New York and John Kendrick of Wyoming to join the cause. Opposition to the President had given way on the farm debenture scheme, Marvin pointed out, but it might not crumple again, even under threat of a veto. Should Hoover decide to reject the bill, Marvin suggested that he modify the tariff by using his authority under the flexible provisions of the Fordney Act. There would be no delay in getting reports out of the Commission for that purpose, since preliminary investigations had been completed

${ }^{12}$ Thomas Marvin, Chairman of the Tariff Commission, to Hoover, July .29, August $6,8,13,15,17,21,22$, Sept. 10, 1929, Pittsburgh Chamber of Commerce to Hoover, Oct. 2, 1929, Ohio Chamber of Commerce to Hoover, October 5, 192, clipping Wall St. Journal, October 5, 1929, Memo by Newton, October 2, 1929, John Edgerton to Hoover, Oct. 1.1, 1929, Hoover Papers, Presidential File, Official File, Tariff Commission, Correspondence, Herbert Hoover Memorial Library, West Branch, Iowa; U.S., Congressional Record, 71st Cong., 1st Sess., 1929, LXXI, Part 4, 4022.

${ }^{13}$ James O. Morris, "The AFL in the 1920s: A Strategy of Defense," Industrial and Labor Relations Review, XI (July 1958), 588; Lyle W. Cooper, "The Tariff and organized Labor," American Economic Review, XX (June 1930), 210-217. 
to send information to the House and Senate during their deliberations. ${ }^{14}$

This was Hoover's greatest strategic strength. With or without the Hawley-Smoot bill, he could adjust duties as he saw fit, within the limits of the Fordney Act. These adjustments would benefit industry more than agriculture, and dissidents realized this. It was for this reason that agrarians had been so critical of the President's program for the Tariff Commission and had refused to give him control over the flexible tariff. But Hoover was firm. In the words of Ted Joslin, Hoover's secretary, "throughout the contest [over the tariff], the President's central idea was to rebuild the Tariff Commission into an effective agency with authority to revise distortions in the tariff. . ." In the conference committee, Hoover finally got what he wanted. ${ }^{15}$

The act retained the principle of setting rates which equalized the costs of production, a concession to the dissidents who feared that without the standard, duties might rise even more. The President, after an investigation initiated by the Commission, either House of Congress, the Chief Executive, or any private party, could either accept or reject the agency's findings. Changes in rates could not exceed fifty percent of those enacted in the legislation. The President could neither ignore the board's reports nor set new rates arbitrarily within assigned limits; nor could he transfer items between the free and dutied lists. The conference committee abolished the Consumer's Counsel, and reinstituted the privileged nature of information obtained from producers. ${ }^{16}$

Hoover was now ready to sign the Tariff Act of 1930, a piece of legislation whose higher duties were never in serious danger of rejection. Indeed, as E. E. Schattschneider has pointed out, Congress could not deal with the tariff from the perspective of the national good. Congressmen who cared

${ }^{14}$ U.S., Congressional Record, 71st Cong., 2d Sess., 1930, LXXII, Part 3, 3033. Unsigned Memo., October 26, 1929, Tariff Commission to Hoover, Hoover Papers, Pres., O.F., T.C., Corresp.

${ }^{15}$ New York Times, May 24, 1930, 1; Theodore G. Joslin, Hoover Off the Record (New York: Doubleday, Doran and Co., 1934), 30.

${ }^{16}$ U.S., Statutes at Large, XLVI, Part 1, 696-707. 
about the economic or international impact of the tariff could come to grips with that issue only on the questions of the flexible program and the future of the Tariff Commission. It was there that Hoover had his real fight. He was determined to control the flexible clause and he would not have a tariff bill without it. In a paper presented to the 1970 meeting of the Organization of American Historians, Jordan A. Schwarz assailed Hoover's legislative leadership during the consideration of the Hawley-Smoot bill. Schwarz correctly emphasized the importance Hoover placed on the flexible provision but erred in implying that this demand was new before Congress. The elastic clause had existed throughout most of the twenties. Unaccountably, Schwarz also states that Congress passed the Tariff of 1930 without Hoover's flexible provision. The President got what he wanted and his legislative leadership on this issue was impeccable. ${ }^{17}$

Judged by its impaot upon the American economy and economic diplomacy, the Tariff Act of 1930 was bad legislation. Retaliation from abroad could cause American producers more harm than any benefit they could derive from the new levels of protection. And Secretary of State Henry Stimson feared that the Department's efforts to negotiate new commercial treaties embodying the unconditional most-favorednation clause would be further impaired. The only good he found in the bill was the flexible tariff which he described as the most constructive step taken in tariff making in many years. But politically-and the tariff was historically a political, domestic issue-the Hawley-Smoot bill was the best that was possible. Hoover's commitment to it, a commitment by a President who believed in high protection, was quite understandable. By the time he received the bill, depression had reinforced his nationalism and protectionist impulses, and he signed it. The flexible provision, he argued, would remedy any of the law's defects. But how effective that device would

${ }^{17}$ E. E. Schattschneider, Politics, Pressures, and the Tariff (New York: Prentice-Hall, 1935), 285; Jordan A. Schwarz, "President Hoover as a Legislative Leader," manuscript copy in hands of author, 2-3. 
be depended ultimately upon Hoover's reorganization of the agency and its performance as a watchdog for American consumers and commerce. It also depended somewhat upon the spread of intelligence throughout the business community. In April 1926, Norman Davis wrote Cordell Hull that for the first time, "the efficient industries that are not hiding behind tariff laws are beginning to realize that the tariff is harmful to them and that they, and not the so-called foreign competitors, are the chief ones in competition with . . . our inefficient industries. . " A cautious assessment of the flexible tariff provision in Business Week during the summer of 1930 indicated that Davis' estimate was becoming an insight. The magazine noted with approval that whereas protected industrialists used to put "their dime in the tariff slot machine and confidently expect to get back at least one dime and maybe fifteen cents, ... there was a good chance under the new system that only a nickel would come out." Exporters and foreign countries would have a tribunal to which they could appeal directly and for the first time the flexible tariff would flex. To some that sounded as though there was a need for lower tariffs and commercial bargaining to expand foreign markets. The United States Chamber of Commerce hinted at the same goal in August, 1930, noting that while it had lobbied for the flexible tariff, it had not worked for the rates of the HawleySmoot Act. ${ }^{18}$

For those who believed that American commercial policy might become more enlightened, Hoover's control and management of the agency was disillusioning. Despite its increased activity, the board did not satisfy critics who argued that the President used it to maintain rather than to readjust

\footnotetext{
${ }^{18}$ Hoover, Memoirs, II, 297-298; Stimson to Republican State Convention of New York, Albany, Sept. 25, 1930, Henry M. Stimson Papers, Sterling Library, Yale University; Elting E. Morison, Turmoil and Tradition: A study of the life and Times of Henry L. Stimson (Boston: Houghton Mifflin, 1960), 312; Wallace McClure to Stimson, April 15, 1929, Stimson to Hoover, June 8, 1929, Foreign Relations of the United States, 1929, Vol. 1, 993-994, 998-999. Davis to Hull, Norman Davis Papers; Filene, "Mass Production and the Tariffs," 43-48; "Flexible Clauses in Tariff May Really Mean More Now," Business Week (July 16, 1930), 27-28; Nations Business, XVIII, Part 2, (August 1930), 14.
} 
duties already too high. In June, 1932, the Commission released data crediting itself with recommendations producing rate reductions on $\$ 44$ million worth of imports and recommendations for rate increases on imports valued at $\$ 17$ million. But left unchanged were requested modifications on items valued at $\$ 147$ million. $^{19}$

All of this energy, remarkable when compared to the Commission's activities during the 1920s, was not enough to prevent another major legislative challenge to Hoover's commercial policy and to his control of the tariff. In early January, 1931, Representative James William Collier of Mississippi introduced a bill reviving the dissident proposals of 1929 and calling for an international conference to set about the task of lowering tariffs. ${ }^{20}$

The Collier bill represented the old progressive, Democratic commitment to a realistic tariff which would promote freer international trade, protect consumers from unnecessary subsidization of manufacturing and expand further America's foreign markets. Though sponsored by a Southerner and a Democrat, it had more than that to remind one of Woodrow Wilson's tariff program. In the Senate, dissidents (36 Democrats and 5 Republicans) modified the bill slightly and sent it on to Hoover. He responded with a strong veto message, claiming that the need for tariff protection was never greater. Those who asked for reduced duties were ignoring the welfare of the American people. Hoover went on to defend at length the effectiveness of the flexible provision and the amount of responsible tariff relief granted under its provisions. If Congress wanted modified rates, it could ask the Tariff Commission to investigate duties under the provisions of Section 336. International conferences were unproductive, and in any case the tariff was a domestic matter. If Congress wanted to enter into reciprocal trade negotiations it should specifically say so. But such a shift, Hoover warned, would

${ }^{10}$ U.S., Tariff Commission, Fifteenth Annual Report (Washington D.C.: Government Printing Office, 1933), 12-14.

${ }^{20}$ U.S. Congréssional Record, 72d Cong., Ist Sess., 1931, LXXV, Part $2,1275,1516$. 
give other nations an opportunity to reduce American agricultural tariffs which in turn would lead to a breakdown of the rural economy, drive farmers to cities, demoralize the nation's economic and social stability and create an economic disaster. This blatant effort to scare votes out of rural based senators made little economic sense for the tariff had yet to help farm prices on major commodities and in 1932 there was not much social stability to lose. But Hoover played upon these fears to freeze votes in Congress. ${ }^{21}$

The House managed only a simple majority over the President's veto. But in the Senate, Democrats led by Cordell Hull, made one last attack, supporting an amendment to the Revenue Act of 1932 which would prohibit all tariff increases for two years. The measure was defeated, 42-35 with all Republicans against and all but two Democrats for. But the core of criticism was still there, and given the absolute terms of Hull's amendment the strength behind it indicated a steady, firm, but minority belief in the Senate that American commercial policy could not be well served through ever higher protection. ${ }^{22}$

Hoover controlled to the end of his administration a tariff and trade policy that remained much the same as the one he had inherited and continued-highly protectionist, isolationist, and provincial. But it was clear from the support in Congress for the Collier Bill and for Hull's amendment to the Revenue Act of 1932 that the times were changing. And in Hoover's initial battle with Capitol Hill over the administrative provisions of the Hawley-Smoot Act there was much that served as a preview for a new approach to the tariff and to commercial policy. Hoover's legislative talents and political maneuvering served his needs midst the writing of an extreme piece of legislation. But it was an achievement, like many of his others, which was soon to be inundated within the tides of the New Deal.

\footnotetext{
${ }^{21} I$ bid., 1932. Part 8, 9149-9155, Part 9, 10035-10037.

${ }^{22}$ John Robert Moore, Senator Josiah William Bailey of North Carolina (Durham, North Carolina; Duke University Press, 1968), 85-86; U.S., Congressional Record, 72d Cong., Ist Sess,, 1932, LXXV, Part 10, 10782, 10799, 10908, 10945, 11127.
} 
Copyright of Annals of Iowa is the property of State of Iowa, by \& through the State Historical Society of Iowa and its content may not be copied or emailed to multiple sites or posted to a listserv without the copyright holder's express written permission. However, users may print, download, or email articles for individual use. 